\title{
TINJAUAN YURIDIS PENERAPAN DIVERSI PADA KASUS ANAK PENGGUNA NARKOBA DI PENGADILAN NEGERI TULUNGAGUNG
}

\author{
Monica Sri Astuti Agustina, Erly Pangestuti, Surjanti, Prisca Oktavia Christi; \\ Fakultas Hukum Universitas Tulungagung, Jln. Ki Mangun Sarkoro, Boyolangu-Tulungagung; \\ E-mail: monicasriastuti1961@gmail.com, sherly8080@gmail.com, surjanti.unita@gmail.com,
}

\section{Octaviachristi@gmail.com}

\begin{abstract}
Abstrak
Semua anak berhak memperoleh proteksi, tidak terkecuali anak yang berhadapan dengan hukum. Mereka berhak memperoleh "proteksi spesial". Hal ini sejalan dengan pertimbangan peraturan dalam sistem peradilan pidana anak, dimana kewajiban negara salah satunya adalah memberikan anak yang sedang berkonflik suatu bentuk perlindungan khusus dan solusi yang akan dipergunakan dengan jalan pendekatan restoratif justice pada pelaksanaan. Tetapi saat diversi dilaksanakan, ternyata banyak ditemukan berbagai persoalan, peraturannya tumpang, dan muncul berbagai hambatan saat pelaksanaannya. Tujuan dari penelitian yuridis empiris ini adalah memberikan gambaran pengetahuan mengenai tinjauan yuridis dari penerapan diversi dalam proses penanganan perkara pidana anak di Pengadilan Negeri Tulungagung dan analisis yang akurat mengenai efektifitas penerapan diversi dalam penanganan perkara anak. Dari hasil penelitian ini, dihasilkan sudut pandang penerapan pelaksanaan diversi dan faktor yang menjadi penghambat dari upaya pelaksanaan diversi di Pengadilan Negeri Tulungagung.
\end{abstract}

Kata Kunci: Tindak Pidana Anak, Penerapan Diversi, Pengadilan Negeri Tulungagung

\section{Abstract}

All children have the right to protection, including children in conflict with the law. They are entitled to "special protection". is in line with regulatory considerations in the juvenile criminal justice system, where one of the obligations of the state is to provide children in conflict with a special form of protection and solutions that will be used by way of a restorative justice approach in implementation. But when the diversion was implemented, it turned out that many problems were found, the regulations overlapped, and various obstacles emerged during its implementation. The purpose of this empirical juridical research is to provide an overview of knowledge regarding the juridical review of the application of diversion in the process of handling juvenile criminal cases at the Tulungagung District Court and an accurate analysis of the effectiveness of the application of diversion in handling children's cases. From the results of this study, the perspective on the implementation of diversion efforts and the factors that hinder the implementation of diversion efforts in the Tulungagung District Court are generated.

Keywords: Child Crime, Application Of Diversion, Tulungagung District Court

\section{PENDAHULUAN}

\section{Latar Belakang}

Masa fase kehidupan manusia, pada suatu waktu akan juga melangsukan pernikahan dan membentuk sebuah keluarga baru. Dalam pernikahan tersebut, hadirnya seorang anak merupakan hal yang sangat dinanti-nantikan. Karena anak merupakan sebuah anugerah, anak merupakan penerus lanjut dari sebuah generasi/keturunan dan di dalam sebuah keluarga, tanpa hadirnya sosok anak akan membuat kondisi keluarga menjadi kosong dan hampa. Dalam Undang-Undang Nomor 23 Tahun 2002 tentang Perlindungan Anak (UUPA), juga disebutkan mengenai pengertian anak, yang intinya menerangkan bahwa anak itu sebuah amanah, sebuah karunia dari Tuhan YME yang harus selalu di jaga ${ }^{1}$. Dari inti pengertian tersebut, bisa diambil kesimpulan sosok anak

${ }^{1}$ Undang-Undang Nomor 23 Tahun 2002 tentang Perlindungan Anak 
itu merupakan pelaku dan juga merupakan peninggalan yang sangat-sangat istimewa, yang dipunyai oleh suatu negeri, keberadaannya itu bisa berguna untuk keberlangsungan hidup suatu negeri pada waktu kini, esok dan yang akan datang, tiaptiap anak nantinya akan menggantikan kepemimpinan dari generasi sebelumnya, tiaptiap anak juga akan memikul tanggung jawab di kemudian hari/hari esok untuk mengantikan generasi tua, yang mana generasi tua saat ini masih bekerja untuk tonggak keberadaan suatu negeri. Dari pentingnya keberadaan sosok anak tersebut, anak seharusnya memiliki dan juga memperoleh peluang yang luas, gunanya adalah untuk pertumbuhan dan perkembangannya secara ekstra dan juga maksimal, dari sisi jiwanya, raganya, mentalnya, potensinya, bakatnya maupun pergaulan di kehidupan sosia bermasyarakat, serta dalam hal pembinaan akhlak yang mulia, serta adapula untuk mewujudkan dari kondisi tesebut, membutuhkan suatu upaya proteksi dalam proses pengawalan untuk mewujudkan perihal tersebut. Proteksi Anak itu, sebetulnya merupakan rangkaian dari sebuah kegiatan yang mempunyai sifat jaminan dan juga perlindungan anak yang seharusnya menjadi suatu tanggung jawab dan juga kepentingan bersama, karena bagaimanapun juga ditangan anak-anak sebagai generasi penerus, kemajuan suatu bangsa akan dipastikan dan kelangsungan generasi sebuah keluarga akan terjamin.

Pada dasarnya mengenai hak anak itu juga diatur di dalam Undang-Undang Dasar Negara Republik Indonesia 1945 (UUD NRI 1945) dan juga Konvensi Perserikatan Bangsa-Bangsa, yang mana itu berisikan tentang aturan penting mengenai perlindungan hukum dari seorang anak, dan juga mengenai kewajiban dalam memberikan perlindungan khusus pada anak yang sedang berhadapan dengan hukum². Adapun perlindungan untuk anak itu, bisa dimulai dari bagian terkecil keluarga yaitu orang tua, saudara-saudara, kerabat, tetangga dan masyarakat sekitar. Semuanya mempunyai tanggung jawab yang besar dalam memberikan penjagaan dan pemeliharaan hak asasi seorang anak, yang mana sesuai dengan kewajiban yang dibebankan oleh hukum. Adapun di dalam Pasal 28 ayat (2) UUD NRI 1945 yang intinya memberikan pengertian bahwa tiap anak itu mendapatkan hak untuk kelangsungan hidup, tumbuh, dan berkembang, juga mendapatkan hak untuk dilindungi.

Dewasa ini, juga tak jarang anak yang berhadapan dengan hukum. Anak yang berhadapan dengan hukum tersebut, terkadang dalam perjalanannya itu dijadikan/dipandang sebagai anak yang berkonflik (mempunyai konotasi negatif). Dari situ, Anak yang berkonflik dengan hukum tersebut, kata lainnya adalah wajib di proses dengan peraturan perundang-undangan yang berlaku di Indonesia. Sistem peradilan pidana anak yang berhadapan dengan hukum dimulai dari tahapan penyelidikan sampai dengan tahap pemidanaan terdapat aturannya di dalam Undang-Undang No. 11 Tahun 2012 tentang Sistem Peradilan Pidana Anak (UU Sistem Peradilan Pidana Anak). Di dalam undang-undang tersebut terdapat pasal mengenai tipe hukuman-hukuman tindak pidana anak semacam pengembalian kepada orang tua, pelayanan warga, kurungan,

2 Sigit Angger Pramukti \& Primarharsya Fuadi. (2014). Sistem Peradilan Pidana Anak. Yogyakarta : Madpress, h. 38 
ataupun penahanan, disini juga dikatan mengenai hukuman pada anak itu tidak dibolehkan untuk dijatuhi hukuman seumur hidup/pun pidana mati, karena kalau dijatuhi hukuman seumur hidup akan bisa mengganggu dari kehidupan di masa depan si anak itu sendiri (mengingat jangka panjang anak bahwa sehabis selesainya masa hukuman tersebut anak tetap menjadi generasi penerus bangsa). Dalam menyelesaikan kasus tindak pidana pada anak tidak boleh kondisinya serta prosesnya dipersamakan dengan tindak pidana yang dilakukan/dicoba oleh orang dewasa, meskipun tipe tindak pidananya itu sama. Peristiwa itu diakibatkan karena anak belum mempunyai penalaran yang sempurna dan juga masih belum bisa mempertanggungjawabkan apa yang telah diperbuat atau dilakukan secara penuh, serta belum mengenali akibat yang telah dijalani dibandingkan dengan aksi percobaan oleh orang dewasa. Maka dari itu, di dalam undang-undang sudah dirancang akan suatu bentuk usaha untuk menghindarkan anakanak pada sebuah hukuman yang dapat memberatkannya dan juga mengecam masa depan langkah anak tersebut, nama dari usaha tersebut adalah diversi. Diversi merupakan suatu pengalihan penyelesaian masalah anak dari proses peradilan pidana ke proses di luar peradilan pidana. Diversi dilakukan dengan maksud supaya mendapatkan suatu keadilan restoratif, dimana keadilan tersebut bisa diterima diantara kedua belah pihak, tanpa adanya hukuman penjara yang akan memberatkan untuk pelaku dari tindak kejadian pidana anak, namun inipula juga tidak melihat sebelah mata keadilan untuk yang menjadi korban pada tindak pidana anak.

Restoratif Justice juga memberikan penjelasan mengenai penyelesaian perkara tindak pidana dengan melibatkan para pihak seperti para pelaku, para korban, para keluarga dari para pelaku/korban, serta para pihak lain yang terkait untuk secara bersama-sama dalam mencari penyelesaian yang adil, dengan titik tekan pada pemulihan kembali pada kondisi awal, dan ini bukan melakukan balasan ${ }^{3}$. Pada usaha diversi diatur kedalam Pasal 5 ayat 2 poin a dan b jo. Pasal 7 UU Sistem Peradilan Pidana Anak, yang intinya bahwa pada proses penyidikan dan penuntutan serta persidangan anak di pengadilan pada lingkungan peradilan umum mempunyai kewajiban untuk melakukan usaha diversi.

Keberadaan dari kepentingan si anak yang menjadi korban, hak serta tanggungjawabnya, dihindarkan dari segala diskriminasi negatif, dihindarkan dari balasan harus diperhatikan dalam tahapan pelaksaanaan diversi. Adapun bentuk dari teori yang menjadi pertimbangan dan juga pendukung dalam penulisan jurnal ini, diantaranya :

1. Pengertian Anak

Ada banyak pengertian mengenai anak, dalam KBBI memuat inti dari pengertian Anak, anak itu bisa dimaksud generasi. Bila ditinjau menurut segi sosiologis, psikologi maupun yuridisnya, mempunyai pengertian yang berbeda. Bisa dilihat dari sudut pandang yuridisnya, contohnya terdapat pada peraturan perundang-undangan, panggilan anak itu mengacu pada umur dari manusia. Anak juga dapat dipahami

\footnotetext{
${ }^{3}$ Barda Nawawi Arief. (2012). Mediasi Penal. Semarang : PPM, h. 45.
} 
sebagai umur manusia tertentu. ${ }^{4}$ Menurut Abu Huraerah anak itu adalah orang yang dilahirkan dari ikatan perkawinan antar suami-istri. ${ }^{5}$

2. Anak berkonflik dengan hukum

Pasal 1 UU Sistem Peradilan Pidana Anak, yang intinya adalah anak itu mempunyai konflik hukum, menjadi korban kriminalitas, menjadi saksi dari tindak kriminalitas. ${ }^{6}$

3. Batasan Usia Pertanggungjawaban Anak

Konvensi dari Hak Anak yang sudah dipakai dan juga sudah diberlakukan di Indonesia adalah Keppres No. 36 Tahun 1996 yang intinya batasan usia anak itu berumur dibawah 18 tahun7. Menurut UU Nomor 3 Tahun 1997 tentang Pengadilan Anak. Adapun batasan usia pada UU Pengadilan anak, batasan usianya antara 8 tahun-18 tahun dan belum menikah. Menurut UU No. 39 Tahun 1999 tentang Hak Asasi Manusia. Pada UU HAM, pengertian batasan usia anak itu juga memiliki perbedaan dari undang-undang/peraturan lainnya. Dan pengertiannya juga sangat dalam, yaitu anak yang di dalam kandungan, belum melaksanakan pernikahan dan juga kurang dari 18 tahun.

4. Tindak Pidana Anak

Pada UU Sistem Peradilan Pidana Anak pada Pasal 1 butir 3 memuat inti dari tindak pidana anak yang mana anak itu masih berusia 12-18 tahun dan anak tersebut telak melakukan perbuatan kriminalitas/pidana. Adapun dalam pasal yang terdapat di BW, tepatnya di pasal 45. Memuat definisi mengenai Tindak Pidana anak yang intinya tindak kriminalitas yang telah diperbuat anak, dan umurnya belum genap 16 tahun. Menurut para ahli dari Bapak A. Syamsudin M dan Bapak Sumaryono, menjelaskan unsur-unsur terkandung dalam tindak kriminalitas, diantaranya ${ }^{8}$ :

1. Perbuatan itu pelakunya manusia.

2. Tindakannya termasuk dalam ketetapan hkum yang sedang berlaku.

3. Terdapat kesalahan

4. Pelaku yang telah terbuat tindak kriminalitas, harus mempertanggung jawabkan tidakanya tersebut.

5. Diversi

Pengertian dari diversi yang terdapat Pasal 1 angka 7 UU Sistem Peradilan Pidana Anak merupakan bentuk dari suatu pemindahaan dari proses penyelesaian urusan tindak kriminalitas yang telah dilakukan oleh anak, dari dari jalan peradilan pidana menuju jalan diluar peradilan pidana.

6. Sistem Peradilan Pidana Anak

\footnotetext{
${ }^{4}$ Tedy Sudrajat. (Agustus 2011). "Perlindungan Hukum terhadap Hak Anak Sebagai Hak Asasi Manusia dalam Perspektif Sistem Hukum Keluarga di Indonesia. Kanun Jurnal Ilmu Hukum: No. 54, Th. XIII, h. 111-112.

${ }^{5}$ Abu Huraerah. (2006). Kekerasan Terhadap Anak. Bandung: Nuansa, h. 36.

${ }^{6}$ Undang-Undang Nomor 11 Tahun 2012 tentang Sistem Peradilan Pidana Anak.

7 Paulus Hadisuprapto. (2010). Delinkuensi Anak. Semarang: Selaras, h. 2.

8 A.Syamsudin Meliala dan E.Sumaryono, 1985, Kejahatan Anak Suatu Tinjauan dari Psikologis dan Hukum, Yogyakarta: Liberty, h. 31
} 
Sistem peradilan pidana anak atau yang dalam bahasa inggrisnya adalah the juvenile system. Itu merupakan gabungan dari beberapa kelembagaan yang tergabung di dalam Pengadilan. Diantaranya adalah Jaksa, Penuntut Umum, Penasehat Hukum, lembaga pengawasan, pusat dari penahanan anak, dan fasilitas dari pembinaan anak. ${ }^{9}$ Sistem peradilan pidana juga merupakan sebuah sistem kontrol dari adanya tindak kejahatan, contohnya adanya kepolisian, kejaksaan, pengadilan dan lembaga permasyarakatan. ${ }^{10}$ Adapun di dalam UU Sistem Peradilan Pidana Anak memuat juga mengenai definisi tersebut, yang intinya merupakan alur penyelesaian perkara mulai awal dalam penyidikan-tahapan dalam bimbingan setelah pelaku menjalani tindak pidana.

Berdasarkan runtutan penjabaran yang telah diuraikan diatas, penulis tertarik dan memutuskan untuk mengkaji dalam judul: "Tinjauan Yuridis Penerapan Diversi pada Kasus Anak Pengguna Narkoba di Pengadilan Negeri Tulungagung".

\section{Rumusan Masalah}

Untuk mempertajam pembahasan dan analisis kasus, maka penulis memilih pokok permasalahan yang akan dibatasi dalam pertanyaan sebagai berikut :

1. Bagaimanakah tinjauan yuridis dalam penerapan diversi pada kasus perkara anak pengguna narkoba di Pengadilan Negeri Tulungagung?

2. Apa sajakah faktor apa yang menjadi penghambat upaya pelaksanaan diversi di Pengadilan Negeri Tulungagung?

\section{METODE PENELITIAN}

Pada penelitian ini, penulis menggunakan suatu metode dengan pendekatan penelitian pada yuridis normatif (metode penelitian hukum normatif/library research). Penelitian yang bersifat yuridis normatif itu dilakukan dengan dasar hukum utama, cara penelitiannya dengan menelaah teori-teori, konsep-konsep, asas-asas hukum serta peraturan perundang-undangan yang berhubungan dengan penelitian ini. Pendekatan dengan metode yuridis normatif ini dikenal dengan nama pendekatan kepustakaan.

\section{PEMBAHASAN}

\section{A. Tinjauan Yuridis dalam Penerapan Diversi pada Kasus Perkara Anak Pengguna Narkoba di Pengadilan Negeri Tulungagung}

Penerapan diversi pada kasus perkara anak pengguna narkoba di Pengadilan Negeri Tulungagung berdasarkan dengan Undang-Undang Republik Indonesia Nomor 11 Tahun 2012 tentang Sistem Peradilan Pidana Anak (UU Sistem Peradilan Pidana Anak) memuat tentang ketentuan pelaksanaan diversi. Diversi merupakan salah satu jalan damai yang dapat diterapkan/digunakan dalam perkara anak, diversi juga menjadi bagian yang sangat signifikan dari suatu metode dalam menyelesaikan perkara pada

\footnotetext{
${ }^{9}$ M. Nasir Djamil. (2013). Anak Bukan untuk Dihukum, Jakarta: Sinar Grafika, h. 43.

${ }^{10}$ Mardjono Reksodiputro. (1993). Sistem Peradilan Pidana Indonesia (Melihat Kepada Kejahatan dan Penegakan Hukum dalam Batas-Batas Toleransi. Jakarta: Fakultas Hukum Universitas Indonesia, h.1.
} 
anak berkasus saat sedang berhadapan dengan hukum. Adanya diversi itu juga bertujuan untuk menjaga hak-hak anak yang berkonflik dengan hukum. Karena pada peradilan pidana anak, kerap terjadi pada tahapan prosesinya cuma mengarah di penegakan hukum dengan proses formalnya dan tidak mengarah pada kepentingan anak yang berkonflik tersebut. ${ }^{11}$ Setiap perkara Anak yang dilimpahkan ke Pengadilan Negeri Tulungagung, maka terlebih dahulu akan diupayakan untuk diversi, jika perkara tersebut sesuai dengan ketentuan/kriteria yang telah ditetapkan oleh aturan UU Sistem Peradilan Pidana Anak. Pada setiap pelimpahan berkas perkara anak yang dilimpahkan oleh pihak kejaksaan merupakan sebuah upaya Pengadilan Negeri Tulungagung terhadap pelaksaan diversi, yang mana pada tahun 2020 setiap perkara anak diupayakan diversi, dan hal tersebut menampakkan hasil yang menggembirakan, terbukti dari penelitian Penulis yang diperoleh dari data SIPP (Sistem Informasi Penelusuran Perkara) pada Pengadilan Negeri Tulungagung perkara anak yang dilimpahkan beberapa diantaranya berhasil di selesaikan secara diversi. ${ }^{12}$ Tiap-tiap orang dihadapan hukum itu memiliki kedudukan yang sama, maka dari itu derajat dari perlindungan terhadap anak itu sepatutnya paling tidak punya tingkat yang sepadan dengan perlindungan orang yang sudah dewasa. ${ }^{13}$ Dalam pelaksanaan diversi di PN Tulungagung, setelah berkas perkara anak dilimpahkan dan diregister dalam sistem untuk mendapatkan nomor perkara, maka ketua pengadilan akan menunjuk salah seorang Hakim anak untuk memeriksa perkara tersebut, dan setelah memeriksa berkas perkara anak tersebut sebelum menetapkan hari sidang, akan terlebih dulu menetapkan Hari Musyawarah Diversi, dimana dalam Penetapan tersebut memuat perintah kepada Penuntut Umum yang melimpahkan perkara untuk menghadirkan anak dan orang tua/wali atau pendampingnya:

a. Yuri Adriansyah, S.H., M.H., sebagai Fasilitator Diversi

b. Naning Rositawati, S.H., M.H., sebagai Panitera pengganti.

c. Yulis Andayani sebagai Pembimbing Kemasyarakatan (PK).

d. Ahmad Arsyad Ramadhan, S.H., sebagai Penasehat Hukum.

e. Much. Fiki Aditiya sebagai anak.

f. Nurkolis sebagai ayah anak.

g. Catur Subagiyo sebagai Kepala Desa Betak.

Setelah musyawarah diversi dilakukan, akan membuahkan beberapa hasil, yang mana nantinya akan dibuat catatan pada berita acara diversi, setelah itu baru akan diberikan tanda tangan sama fasilitator diversi dan panitera. Di dalam kesepakatan diversi tersebut, juga diberikan tanda tangan para pihak dan setelah itu, fasilitator diversi

11 Achmad Ratomi. (Desember 2013). “Konsep Prosedur Pelaksanaan Diversi pada Tahap Penyidikan dalam Penyelesaian Tindak Pidana yang Dilakukan oleh Anak." Jurnal Arena Hukum, Vol. 6, No. 3, h. 395.

${ }^{12}$ Data SIPP (Sistem Informasi Penelusuran Perkara) Pengadilan Negeri Tulungagung, Tahun 2021.

${ }^{13}$ Syamsu Haling, Paisal Halim, Syamsiah Badruddin \& Hardianto Djanggih. (April-Juni 2018). "Perlindungan Hak Asasi Anak Jalanan dalam Bidang Pendidikan menurut Hukum nasional dan Konvensi Internasional." Jurnal Hukum \& Pembangunan, Vol. 48, No. 2, h. 362-363. 
memberikan pelaporan ke ketua pengadilan dan setelah ketua pengadilan melakukan pembacaan dan pemeriksaan hasil kesepakatan tersebut, lalu membuat sebuah penetapan diversi yang didasakan pada kesepakatan diversi yang telah disepakati dan juga diberikan tanda tangan oleh para pihak. Adapun hak dan kewenangan ketua pengadilan itu bisa membatalkan kesepakatan diversi tersebut jikalau tidak bisa mencukupi persyaratan dalam kesepakatan tersebut, yaitu jika kesepakatannya bertabrakan dengan norma hukum, bertabrakan dengan norma agama, bertabrakan dengan kepatutan masyarakat setempat, bertabrakan dengan norma kesusilaan, mencangkup hal-hal yang keberadaannya tidak bisa dilakukan anak dan juga menaruh anutan yang tidak baik. Setelah menerima penetapan dari Ketua Pengadilan, Hakim pemeriksa perkara anak tersebut mengeluarkan penetapan penghentian pemeriksaan perkara. Berdasarkan hasil penelitian penulis, sebagaimana yang diamanat UU Sistem Peradilan Pidana Anak tersebut, Hakim Anak yang memeriksa perkara Nomor 7/Pid.Sus-Anak/2020/PN Tlg melaksanakan diversi dengan mempertimbangkan posisi kasus yang dilakukan oleh anak sebagai berikut:

a) Pada awalnya pelaku anak yang sehari-harinya tinggal dirumah sendiri dikarenakan kedua orang tuanya pergi merantau keluar negeri sebagai Tenaga Kerja Indonesia (TKI) sehingga dengan leluasa telah memiliki shabu dirumahnya yang dibeli dari temannya lalu shabu tersebut biasanya dipakai oleh pelaku anak bersama dengan temannya.

b) Bahwa pada hari Jumat tanggal 20 Maret 2020, saat itu anak Muh. Fiki sedang berada dirumahnya dan saat itu ada temannya yang bernama Shefrizal Alif Hernando yang sedang main kerumah pelaku anak lalu saat itu pelaku anak berniat untuk menghisab shabu atau menyabu tetapi shabunya tidak ada lalu menyuruh temannya yang bernama Shefrizal Alif Hernando untuk membeli shabu dengan menggunakan uang milik anak Muh. Fiki sebesar Rp 200.000,- (dua ratus ribu rupiah) mendapatkan 1 (satu) poket shabu kepada temannya yang bernama Sdr. Dedi.

c) Bahwa selanjutnya Sdr. Shefrizal janjian dengan Dedi di daerah Ngujang untuk mengambil shabu dengan sistem ranjau yang awalnya Sdr. Dedi menghubungi Shefrizal dan memberitahukan bahwa shabu tersebut untuk membeli shabu dan amat Dsn. Krajan 3, Rt. 002 Rw. 005 Desa t disimpan didalam bungkus rokok surya dan ditaruh di pinggir jalan dekat ATM BRI lalu Shefrizal mencari bungkusan tersebut dan setelah ketemu lalu diambil sedangkan uangnya dimasukkan kedalam bungkus rokok surya dan Shefrizal langsung pulang menuju kerumahnya anak Muh. Fiki.

d) Bahwa pelaku anak memiliki shabu tersebut tanpa memiliki ijin, karena pelaku anak bukan sebagai Dokter, Apoteker, serta tidak mempunyai kewenangan untuk itu.

e) Bahwa akhirnya perbuatan anak Muh. Fiki diketahui oleh petugas dari Polsek Bandung lalu dilakukan penangkapan dan ditemukan 1 (satu) buah alat bong, 1 (satu) buah kaca pipet yang berisi sisa shabu, 1 (satu) buah plastik klip bening bersi shabu, 2 (dua) buah korek api, 2 (dua) buah gunting. Bahwa setelah dilakukan pemeriksaan oleh Laboratorium Kriminalistik Cabang Surabaya No.Lab.3274/NNF/2020 tanggal 23 Maret 2020 diperoleh suatu kesimpuan bahwa Barang Bukti Nomor 6291/2020/NNF; 
6292/2020/NNF seperti tersebut dalam (I) adalah benar kristal Metamfetamina terdaftar dalam golongan I (satu) nomor urut 61 Lampiran I UURI No. 35 Tahun 2009 tentang Narkotika, sedang diketahui anak Muh. Fiki untuk/dalam memiliki, menguasai, menyimpan shabu bukan sebagai atau atas nama suatu pabrik obat, pedagang besar farmasi, apotek, rumah sakit, Puskesmas, balai pengobatan, Dokter, lembaga penelitian atau lembaga pendidikan atau bukan berdasarkan resep dokter. Dari uraian alasan perbuatan yang dilakukan oleh anak tersebut, maka Hakim Anak sebagai fasilitator diversi mengupayakan diversi dengan menghadirkan anak yang didampingi oleh Pembimbing Kemasyarakatan (PK), Petugas Balai Pemasyarakatan (Bapas), Penasihat Hukum Anak, orangtua anak dan tokoh masyarakat yaitu Kepala Desa. Setelah pengimplementasian dari musyawarah diversi dibuka oleh fasilitator diversi, dan pelaksanaannya itu tertutup untuk umum. Dikarenakan untuk menjaga privasi dan menjaga mental anak, selanjutnya fasilitator diversi memberikan pertanyaan ke anak yang berkasus dengan hukum, juga orang tua (bisa orang tua kandung, walinya atau juga penasihat hukumnya dari si anak) apakah bersedia untuk diadakannya musyarawah, dan jawaban dari pertanyaan tersebut dari pihak si anak akan memberikan persetujuaan untuk dilaksanakan musyawarah. setelah itu, Fasilitator meneruskan dan memberikan waktu kepada Pembimbing Kemasyarakatan untuk pembacaan dari Laporan Penelitian Kemasyarakatan, diantaranya mengenai :

a) No. Reg. Litmas Nomor : 37/BKA/III/2020/Bps Kdr, tanggal 27 Maret 2020 an. Much Fiki Nur Aditiya bin Nurkolis, dengan rekomendasi/kesimpulan.

b) Terhadap anak untuk diberikan sanksi berupa pidana pokok berupa Pelatihan Kerja sebagaimana dimaksud dalam Pasal 71 ayat (1) huruf c UURI No. 11 Tahun 2012 tentang Sistem Peradilan Anak;

Disamping itu, fasilitator diversi juga memberikan waktu kepada si anak dan keluarganya(bisa orang tua kandungnya sendiri/walinya/penasihat hukumnya untuk menuangkan pendapatnya.

A. Pendapat Anak :

1. Anak mengaku bersalah, menyesali perbuatannya dan berjanji tidak akan mengulangi lagi perbuatan yang melanggar hukum.

2. Anak mengakui apa yang dituduhkan kepadanya adalah benar, dan anak juga memahami bahwa perbuatannya adalah salah dan melanggar hukum yang dapat dijatuhi sanksi pidana.

3. Anak meminta maaf khususnya kepada keluarga, orang tua serta masyarakat pada umumnya yang merasa dirugikan maupun terganggu atas perbuatannya tersebut.

B. Pendapat Orang Tua/Wali/Pendamping

1. Bahwa orang tua/wali merasa sangat prihatin setelah mengetahui anak terlibat pelanggaran hukum dan merasa gagal dalam mendidik anak selama ini.

2. Keluarga menyadari perbuatan yang dilakukan anak adalah bagian dari bentuk kegagalannya dalam mendidik dan menanamkan nilainilai agama sejak dini kepada anak serta kurangnya pengawasan dan perhatian terhadap anak, sehingga anak melakukan pelanggaran hukum. 
3. Keluarga akan melakukan koreksi dan pelajaran kedepan dalam mendidik anak dengan yang lebih baik, agar tidak melakukan pelanggaran hukum lagi;

Selain itu fasilitator diversi juga memberikan kesempatan kepada penasihat hukum untuk memberikan pendapat terhadap perbuatan yang telah dilakukan anak Much Fiki Nur Aditiya Bin Nurkolis, sebagai berikut:

Untuk anak Much Fiki Nur Aditiya Bin Nurkolis, sependapat dengan Pembimbing Kemasyarakatan dan memberi rekomendasi/kesimpulan: Terhadap anak untuk diberikan sanksi berupa pidana pokok berupa Pelatihan Kerja sebagaimana dimaksud dalam Pasal 71 ayat (1) huruf c UURI No. 11 Tahun 2012 Tentang Sistem Peradilan Anak.

Adapun saat musyawarah Diversi tersebut, Fasilitator juga mempersilahkan pada perwakilan dari masyarakat yang hadir untuk memberikan masukan dan juga saran dalam mengakhiri konflik tentang perbuatan yang telah si Anak lakukan:

1. Perbuatan tindak pidana yang dilakukan anak dan kawan-kawannya, diantaranya adalah salah satu faktor tidak adanya / kurangnya pengawasan dan bimbingan dari orang tua, karena orang tua bekerja di luar negeri;

2. Dengan kejadian ini cermin/ contoh buat para remaja untuk tidak melakukan hal yang seharusnya tidak dilakukan para anak kelak sebagai pembelajaran, agar tidak mengulangi lagi.

Setelah mempersilahkan para pihak dalam menyampaikan masukan serta saran dan juga menyaring pertimbangan-pertimbangan yang dikemukakan oleh para pihak tersebut, maka di dapatkan hasil dari kesepakatan diversi yang dituangkan dalam kesepakatan diversi yang telah dikemas dalam beberapa pasal di bawah ini:

Pasal 1 Bahwa Pihak I (Wali) bersedia untuk :

1. Mendidik dan mengawasi Much Fiki Nur Aditiya Bin Nurkolis, dengan cara mengawasi tingkah laku, pergaulan teman-temannya dan juga bekerja sama dengan tetangga sekitar untuk ikut mengawasi anak tersebut.

2. Menyerahkan kepada kantor desa mengawasi kepada Much Fiki Nur Aditiya Bin Nurkolis untuk melakukan pelayanan masyarakat dalam jangka waktu selama 3 (tiga) bulan.

Pasal 2 Bahwa Pihak II menyepakati untuk:

1. Mengembalikan untuk mendidik dan mengawasi Much Fiki Nur Aditiya Bin Nurkolis, kepada Pihak Pertama (wali) Dengan cara mengawasi tingkah laku, pergaulan temantemannya dan juga bekerja sama dengan tetangga sekitar untuk ikut mengawasi anak tersebut

2. Menyerahkan Much Fiki Nur Aditiya Bin Nurkolis kepada kantor desa untuk mengawasi anak tersebut pada saat melakukan pelayanan masyarakat dalam jangka waktu selama 3 (tiga) bulan.

Pasal 3

Sdr. Catur Subagiyo, perangkat desa Betak, dan Sdr. Yulis Andayani selaku petugas dari kantor Bapas Kediri, Sepakat untuk menerima kesepakatan yang dilakukan oleh para pihak sebagaimana dalam pasal 1 dan pasal 2 kesepakatan ini.

Pasal 4

Semua pihak bersepakat untuk dilakukan / menyelesaikan perkara ini dengan jalan diversi dan proses perkara dihentikan ;

Pasal 5

Apabila kesepakatan ini tidak dipenuhi para pihak maka proses pemeriksaan dilanjutkan dalam proses persidangan 
Pasal 6

Kesepakatan ini dibuat oleh para pihak tanpa adanya unsur paksaan, kekeliruan dan penipuan dari pihak manapun. Dari hasil Kesepakatan Divrsi yang berhasil tersebut, maka akan dilaporkan pada Ketua Pengadilan oleh Hakim Anak yang menangani perkara tersebut, dan berdasarkan dari Laporan Hasil Diversi maka Ketua Pengadilan akan membuat Penetapan dengan mempertimbangkan bahwa kesepakatan diversi tersebut telah memenuhi dan tidak bertentangan dengan peraturan perundang-undangan, sehingga beralasan untuk dikabulkan, dan dengan memperhatikan ketentuan Pasal 12, Pasal 52 ayat 5 UU Nomor 11 Tahun 2012 tentang Sistem Peradilan Pidana Anak dan Undang-Undang Nomor 8 Tahun 1981 tentang Hukum Acara Pidana serta peraturan perundang-undangan lain yang bersangkutan;

MENETAPKAN :

1. Mengabulkan Permohonan Hakim;

2. Memerintahkan para pihak untuk melaksanakan kesepakatan diversi;

3. Memerintahkan Hakim untuk mengeluarkan penetapan penghentian pemeriksaan setelah kesepakatan Diversi dilaksanakan seluruhnya/sepenuhnya.

4. Memerintahkan agar barang bukti dikembalikan kepada Penuntut Umum dalam hal kesepakatan diversi telah dilaksanakan seluruhnya/sepenuhnya.

5. Memerintahkan Panitera menyampaikan salinan penetapan ini kepada Penyidik Anak/Penuntut Umum/Hakim, Pembimbing Kemasyarakatan, Anak/Orang tua, Tokoh Masyarakat dan para Saksi.

Setelah dikeluarkannya Penetapan Diversi oleh Ketua Pengadilan, maka Selanjutnya Hakim Anak yang memeriksa perkara Anak mempertimbangkan Penetapan Diversi tersebut dan membuat Penetapan Penghentian Perkara dengan Memperhatikan ketentuan Pasal 7, Pasal 52 ayat 5 UU Nomor 11 Tahun 2012 tentang Sistem Peradilan Pidana Anak dan UndangUndang Nomor 8 Tahun 1981 tentang Hukum Acara Pidana serta peraturan perundangundangan lain yang bersangkutan, yang isinya

MENETAPKAN

1. Menyatakan pemeriksaan perkara pidana Nomor 7/Pid.SusAnak/2020/PN.Tlg., "DIHENTIKAN";

2. Memerintahkan Panitera menyampaikan salinan penetapan ini kepada Penyidik Anak/Penuntut Umum, Pembimbing Kemasyarakatan, Anak/Orang tua, dan Korban/Orang tua;

Dengan adanya penetapan penghentian perkara tersebut, maka perkara Anak Nomor 7/Pid.Sus-Anak/2020/PN.Tlg tidak dilanjutkan pemeriksaannya ke proses persidangan. Dengan dihentikannya perkara anak, maka upaya diversi dalam tindak pidana anak telah berhasil dalam menangani stigma negatif pada anak pelaku tindak pidana dan cukup membuat efek jera bagi si anak yang berhadapan dengan hukum, agar dapat memperbaiki perilakunya di kemudian hari. Diversi dapat menjadikan sarana penyembuh atau obat dari faktor-faktor yang mempengaruhi perilaku yang menyebabkan tindak pidana di atas dengan maraknya kenakalan remaja/anak.

\section{B. Faktor-Faktor yang Menghambat Upaya Pelaksanaan Diversi di Pengadilan Negeri Tulungagung}

Tujuan dari adanya diversi salah satunya adalah memberikan jaminan pada anak dalam hal dilindungi, diayommi, juga merupakan wujud dari membantu masyarakat dilingkup dunia hukum, juga memberikan wadah dari penyelesaian seputar dunia hukum, yang mana sampai saat ini belum adanya jaminan dari perbaikan yang lebih menjamin pemulihan yang lebih mengarah pada kemanusiaan ketimbang prosedur proses pelabelan/cap melewati alih bentuk dari tahapan pada pidana formal ke tahapan 
alternatif. Pada tempat di tahapan ini akan berdampak baik pada para pihak, yaitu dambaan dari terwujudnya suatu situasi kondisi damai. Namun jarang terwujud banyak saat mengimplementasikan dari penerapan diversi. Sering kali menemukan adanya kegagalan atau keberhasilan. Dari tahapan tersebut, berkaitan erat dengan pekerjaan hukum dan suatu produk hukumnya. Kriteria dari tugas yang berjalan dengan baik atau tidak dari hukum, ada tiga kriteria unsur yang melahirkan sistem, yaitu pada Substansi, pada Struktur, serta pada Budaya Hukumnya. Dari ketiganya tersebut, akan dijadikan patokan dasar dari suatu hukum itu apakah bisa terus jalan dengan baik ataupun tidak.

Dari penjabaran tersebut, penulis menemukan faktor-faktor yang mungkin bisa menjadi penghambat, diantaranya:

1. Faktor Pertama Substansi Hukum

Pada substansi Hukum bisa dilihat di tahapan koordinasi, dimana Hakim sebagai fasilitator melaksanakan tugas kewajibannya dengan memberikan penawaran pada para pihak yang berperkara dalam kasus ini (acuannya pada UU Sistem Peradilan Anak). Di tahapan ini, Hakim dihadapkan pada hasil penawaran yang terkadang dari salah satu pihak tidak mau untuk proses diversi. Dari sini, upaya proses diversi bisa berujung kegagalan. Bisa dilihat pada implementasinya masih bergantung pada para pihak, ini merupakan kelemahan dari mengimplementasikan Undang-Undang tersebut.

2. Faktor selanjutnya terletak di aparat penegak hukumnya.

Penulis mempunyai pendapat tentang faktor ini "Tidak semua Hakim pada Pengadilan Negeri Tulungagung mempunyai sertifikat sebagai Hakim Anak, sedangkan perkara anak membutuhkan perhatian dan penanganan khusus, sehingga oleh karena sibuk dengan perkara yang lain pada saat Hakim tersebut mendapatkan perkara anak maka langsung ditetapkan hari sidang pada sistem informasi penelusuran perkara, tanpa terlebih dahulu menetapkan Hari Musyawarah Diversi, dengan demikian tidak semua perkara anak dilakukan diversi".

3. Faktor yang selanjutnya ditemukan oleh penulis saat meneliti di Pengadilan Negeri Tulungagung, faktornya ditinjau dari kultur hukum yang berkembang di masyarakat. Adanya anggapan di masyarakat, kalau ada anak yang melakukan tindak pidana maka pelakunya telah melampaui batasan dari tata aturan yang ada di masyarakat. Maka pelaku tersebut harus dipenjara, supaya merasakan penderitaan dan melakukan pertobatan atas tindakannya tersebut. Dan itupun harus berakhir di dalam meja hijau ataupun di dalam jeruji besi. Seharusnya budaya dan juga mainset seperti ini harus dihilangkan, karena dampak jangka panjangnya bisa merusak psikis anak tersebut dan masa depannya bisa terancam. Harus perlu diingat masih adanya cara lain seperti diversi yang lebih menghargai hak anak yang jadi pelaku. 


\section{PENUTUP}

Dalam pelaksanaan diversi di Pengadilan Negeri Tulungagung telah dilaksanakan sebagaimana yang disyaratkan oleh Peraturan Mahkamah Agung Republik. Upaya Pengadilan Negeri Tulungagung terhadap pelaksanaan diversi terbukti membuahkan hasil yang menggembirakan, dimana tahun 2020 setiap perkara anak diupayakan diversi, dan dari 16 perkara anak yang dilimpahkan, 5 perkara diantaranya berhasil diselesaikan secara diversi. Peran dari diversi sangat serius, keberadaannya merupakan cara paling penting dalam menyelesaikan perkara yang berhubungan dengan kriminalitas anak, selain merupakan jalan anak untuk mendapatkan perlindungan hukum, saat ini jalan diversi diharapkan dan dilihat bisa mampu untuk memberikan pengertian pada anak untuk tidak jatuh ke tindakan kriminalitas. Adanya beberapa faktor yang menyebabkan kegagalan dalam upaya pelaksanaan diversi di Tulungagung, yakni yang kesatu substansi hukum berkaitan dengan UU Sistem Peradilan Pidana Anak yang mengatur tentang peraturan diversi, yang kedua yaitu dari segi oknum dari penegakan hukumnya yaitu Hakim Anak yang ditujuk oleh Ketua Pengadilan Negeri Tulungagung berdasarkan penetapan penunjukan Hakim Anak, serta yang ketiga adalah kultur hukum adanya anggapan di masyarakat, kalau ada anak yang melakukan tindak pidana maka pelakunya telah melampaui batasan dari tata aturan yang ada di masyarakat. Maka pelaku tersebut harus dipenjara, supaya merasakan penderitaan dan melakukan pertobatan atas tindakannya tersebut. Dan itupun harus berakhir di dalam meja hijau ataupun di dalam jeruji besi.

Anak sebagai generasi penerus bangsa harusnya memiliki masa depan yang gemilang. Untuk mewujudkan harapan tersebut, semua itu berada pada tanggung jawab seluruh elemen bangsa. Itupun tidak ada pengecualian pada anak yang sedang berkonflik, serta berhadapan dengan prosesi hukum. Adapun langkah agar anak yang berhadapan dengan hukum tersebut bisa dilindungi dan dijaga dengan jalan diversi, maka penulis menyarakan bahwa:

a. Agar Hakim Anak benar-benar mempertimbangkan patut tidaknya semua perkara anak untuk dilakukan diversi dengan mencermati posisi kasus, pendapat-pendapat anak/orang tua/wali/ pendamping/ penasihat hukum, hasil laporan penelitian dan kemasyarakatan dari pembimbing kemasyarakatan, dan juga pendapat perwakilan masyarakat tentang perilaku anak, sehingga musyawarah diversi dapat dilaksanakan dan juga berhasil.

b. Hendaknya dalam proses diversi agar Hakim sebagai fasilitator diversi memberikan pemahaman kepada para pihak terkait tentang pentingnya proses diversi, sehingga pihak terkait benar-benar memahami arti pentingnya diversi dan dapat tercapai kesepakatan antara anak dengan pihak terkait. Sehingga hal-hal yang menjadi penghambat upaya diversi dapat diminimalisir seminimal mungkin. 


\section{DAFTAR PUSTAKA}

Angger Pramukti, Sigit \& Fuadi, Primarharsya. (2014). Sistem Peradilan Pidana Anak. Yogyakarta: Madpress.

Data SIPP (Sistem Informasi Penelusuran Perkara) Pengadilan Negeri Tulungagung

Djamil, M. Nasir. (2013). Anak Bukan untuk Dihukum. Jakarta: Sinar Grafika.

Hadisuprapto, Paulus. (2010). Delinkuensi Anak. Semarang: Selaras.

Haling, Syamsu, Paisal Halim, Syamsiah Badruddin, \& Hardianto Djanggih. (2018). "Perlindungan Hak Asasi Anak Jalanan Dalam Bidang Pendidikan Menurut Hukum Nasional Dan Konvensi Internasional". Jurnal Hukum \& Pembangunan, Vol. 48, No. 2, April-Juni 2018.

Huraerah Abu. (2006). Kekerasan terhadap Anak. Bandung: Nuansa.

Meliala, A.Syamsudin dan E.Sumaryono. (1985). Kejahatan Anak Suatu Tinjauan dari Psikologis dan Hukum, Yogyakarta: Liberty.

Nawawi Arief, Barda. (2012). Mediasi Penal. Semarang: PPM.

Peraturan Mahkamah Agung RI Nomor 4 Tahun 2014

Putusan Perkara Pengadilan Negeri Tulungagung tanggal 16 Juni 2020 Nomor 7/Pid.SusAnak/2020/PN Tlg

Ratomi, Achmad. (2013). "Konsep Prosedur Pelaksanaan Diversi pada Tahap Penyidikan dalam Penyelesaian Tindak Pidana Yang Dilakukan Oleh Anak", Jurnal Arena Hukum, Vol. 6, No. 3, Desember 2013.

Tedy Sudrajat. (2011). "Perlindungan Hukum terhadap Hak Anak Sebagai Hak Asasi Manusia dalam Perspektif Sistem Hukum Keluarga di Indonesia." Kanun Jurnal Ilmu Hukum: No. 54, Th. XIII, Agustus, 2011.

Undang-Undang Dasar Negara Republik Indonesia 1945

Undang-Undang Nomor 11 Tahun 2012 tentang Ketentuan Pelaksanaan Diversi

Undang-Undang Nomor 11 Tahun 2012 tentang Sistem Peradilan Pidana Anak

Undang-Undang Nomor 23 Tahun 2002 tentang Perlindungan Anak

Undang-Undang Nomor 3 Tahun 1997 tentang Pengadilan Anak

Undang-Undang Nomor 39 Tahun 1999 tentang Hak Asasi Manusia

Undang-Undang Nomor 8 Tahun 1981 tentang Hukum Acara Pidana 